\title{
Strategieë om die implementering van die Suid-Afrikaanse professionele leergemeenskapmodel te bevorder
}

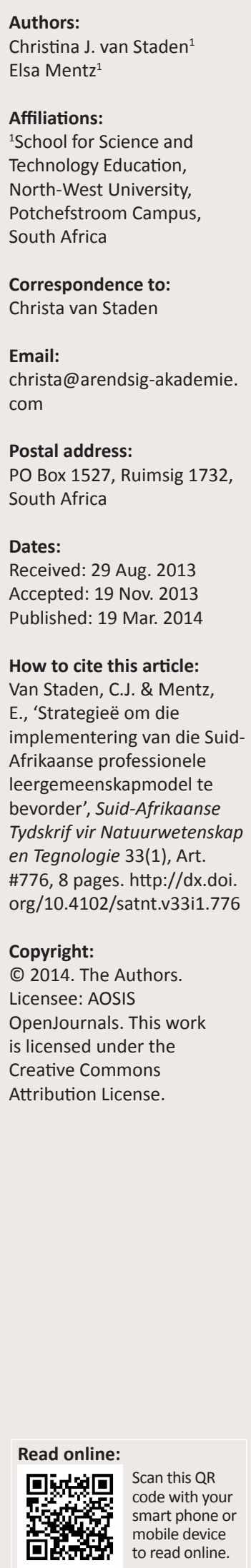

Die Gë̈ntegreerde Strategiese Beplanningsraamwerk vir Onderwyseropleiding en -ontwikkeling in Suid-Afrika 2011-2025 vereis dat vakverwante professionele leergemeenskappe tussen 2011 en 2017 op skool- en distriksvlak gevestig word. Die doel daarvan is om onderwysers van geleenthede te voorsien om hul eie leerbehoeftes te identifiseer en te vervul. Slegs sommige van die Distriksonderwysersontwikkelingsentra wat as vergaderplekke moet dien, hoef egter teen 2025 gereed te wees. Die gaping tussen beleid en die implemetering daarvan kan die vestiging van professionele leergemeenskappe rem en selfs verhoed. Drie implementeringsprobleme wat die professionele leergemeenskapmodel op die berugte onderwyshervormingsiklus kan stuur, word geïdentifiseer ten einde strategieë aan die hand te doen om die probleme op te los. Die ondersoek het tot die voorstel gelei dat 'n gekoördineerde benadering noodsaaklik geword het ten einde te verhoed dat die professionele leergemeenskapmodel die prooi van die berugte onderwyshervormingsiklus word.

Strategies for a smooth implementation of the South African professional learning community model. The Integrated Strategic Planning Framework for Teacher Training and Development in South Africa 2011-2025 requires that subject-related professional learning communities should be established widely between 2011 and 2017. However, only some of the District Teacher Development Centres that are intended to provide meeting places need to be up and running by 2025 . The gap between policy and implementation can impede or even prevent the establishment of professional learning communities. Three implementation problems were identified that could catapult the professional learning community model into the infamous education reform cycle, and strategies are proposed for a smooth implementation. It is proposed that a coordinated strategy be followed to prevent the South African professional learning community model falling prey to the reform cycle.

\section{Behoefte aan deurlopende professionele ontwikkeling}

Barth (1997) het teen die einde van die vorige eeu gemaan dat die vinnig veranderende 21ste-eeuse wêreld daartoe bydra dat opleidingsinstansies studente met die basiese kennis, vaardighede en tegnieke kan toerus om in diens geneem te word, maar hulle nie volledig kan toerus om oor 'n tydperk van 40 jaar suksesvol in hul beroepe te staan nie. In die Suid-Afrikaanse konteks vererger die nypende onderwysertekort die probleem, aangesien onder- en ongekwalifiseerde onderwysers in diens geneem moet word om die tekort aan te vul. Die omvang van hierdie probleem blyk uit statistieke wat in 2010 deur die Departement van Basiese Onderwys vrygestel is (Departemente van Basiese Onderwys en van Hoër Onderwys en Opleiding 2011). Die vermelde statistieke toon dat $48 \%$ van die 2010-onderwyserkorps onvoldoende gekwalifiseerd was (vergelyk Figuur 1).

Dit is dus moontlik dat ' $n$ beduidende groep onderwysers nie oor die basiese kennis, vaardighede of tegnieke beskik om hul werk effektief te verrig nie. Dit is ook moontlik dat die groep onen ondergekwalifiseerde onderwysers 'n behoefte aan die regte inligting, kennis, raad, leiding, ondersteuning, ervaring en konkrete bronne kan ervaar om hul werk effektief te verrig. Hierdie behoefte is egter nie tot on- en ondergekwalifiseerde onderwysers beperk nie. Onlangse navorsing toon dat selfs hoogs gekwalifiseerde onderwysers byna daagliks ' $n$ behoefte aan toegang tot hierdie groep sosiale bronne ervaar (Van Staden 2012). Na aanleiding van hierdie stel feite kan die noodsaaklikheid van die deurlopende professionele ontwikkeling van onderwysers nie onderskat word nie.

Die staat het sedert die eeuwending verskeie onderwyshervormings ontwerp om die deurlopende professionele ontwikkeling van onderwysers te bevorder, dog met weining effek op die prestasie van leerders. In 'n hernude poging om ' $n$ krisis af te weer, word daar vereis dat onderwysers professionele leergemeenskappe moet vestig met die doel om hul eie leerbehoeftes te identifiseer 


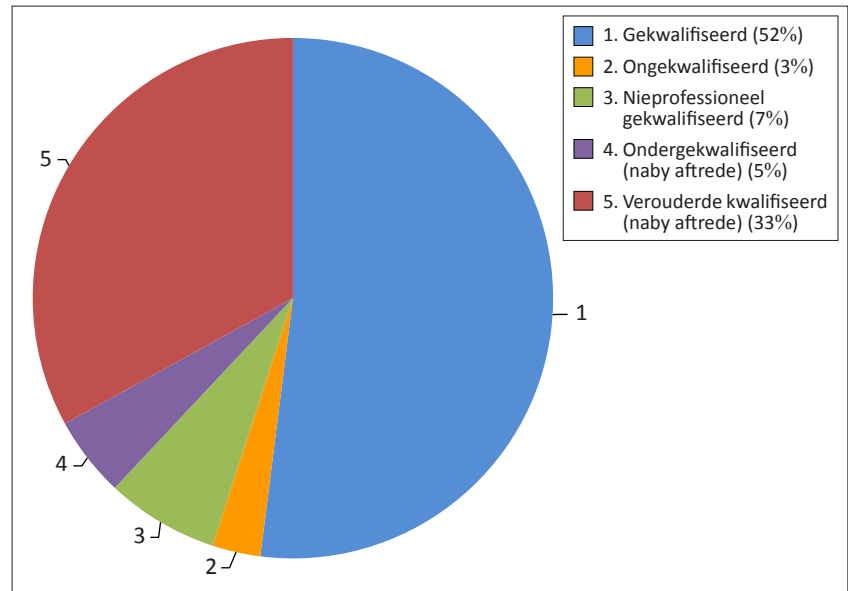

FIGUUR 1: 2010-statistieke in verband met die opleiding van Suid-Afrikaanse onderwysers in vergelyking met SAOU (2010).

en vervul (Departemente van Basiese Onderwys en van Hoër Onderwys en Opleiding 2011). Professionele leergemeenskappe kan wel 'n positiewe impak op die werksverrigting van onderwysers en dus leerderprestasies uitoefen (DuFour 2004; Bolam et al. 2005; DuFour \& DuFour 2012) mits die model vaatbelyn geïmplementeer word.

DuFour (2004) het bykans 'n dekade gelede reeds gewaarsku dat die professionele leergemeenskapmodel 'n kritieke kruispad bereik het en neig om die prooi van die onderwyshervormingsiklus te word. So 'n siklus ontstaan wanneer onafwendbare implementeringsprobleme die aanvanklike entoesiasme demp en tot die afskaffing van die hervorming (kan) lei (DuFour 2004).

Die doel van die navorsing waaroor hier verslag gedoen word, was om die vernaamste implementeringsprobleme te identifiseer sodat aanbevelings aan die hand gedoen kon word om sulke probleme op te los. Die volgende twee probleemvrae het die ondersoek gerig:

- Wat is die vernaamste probleme waarmee die implementering van die professionele leergemeenskapmodel in Suid-Afrikaanse konteks gekonfronteer word?

- Watter strategieë kan aangewend word om die professionele leergemeenskapmodel vaartbelyn te implementeer?

Die res van die artikel is soos volg gestruktureer: na 'n kort uiteensetting van die kennisteoretiese en metodologiese aannames, word die konseptueel-teoretiese raamwerk kortliks bespreek. Daarna word sekere implementeringsprobleme en strategieë om hierdie probleme te oorkom bespreek. Die artikel word afgesluit met ' $n$ bespreking van die implikasies vir die onderwys en 'n oorkoepelende gevolgtrekking.

\section{Kennisteoretiese en metodologiese aannames}

Die navorsing is vanuit 'n pragmatiese wêreldbeskouing onderneem. Daar is nie geredeneer watter teorie die geskikste is nie omdat geen enkele leerteorie al die antwoorde kan verskaf nie. Die keuse van metode is eerder gebaseer op hoe goed die teorie of metode kan werk om probleme op te los
(Johnson \& Ombuegbuzie 2004). 'n Teorie kan nie as reg of verkeerd bewys word nie, maar eerder as bruikbaar om waarnemings te verklaar en nuwe navorsing te stimuleer (Hegerhahn \& Olsen 1992). Indien 'n teorie bydra om te verduidelik waarom iets gebeur het, word nuwe kennis geskep wanneer die teorie bevestig en ontwikkel word (Didloft 2010). Sosiale Netwerk Analise het voorts 'n bruikbare lens gebied om die probleme van nader te beskou.

Netwerkbenaderings verskil van tradisionele benaderings omdat die fokus op 'n versoening tussen teorie en praktyk geplaas word (Veugelers \& Zijlstra 2002). Daar is van die veronderstelling uitgegaan dat die kennis om werk effektief te verrig intiem verbind is met (en geskep word in) die sosiale, historiese en omgewingskonteks waarin kennis en menswees oorweeg en betekenisvol geag word (Weems 1999). Hierdie sosiale konteks bestaan uit 'n aantal onderwysers en die sosialebande ${ }^{1}$ wat hulle in 'n ontwikkelingsnetwerk ${ }^{2}$ verweef. Sosiale Netwerk Analise bied beide die teorie en 'n pragmatiese metode om die ontwikkelingsnetwerke te verken (Van Staden 2012), iets wat nodig is om te verstaan hoe die professionele leergemeenskapmodel geïmplementeer kan word.

Die pragmatiese benadering het dit moontlik gemaak om intuïtiewe, gesaghebbende en logiese kennis te integreer om te verstaan watter strategieë aangewend kan word om professionele leergemeenskappe te vestig. Die konseptueelteoretiese raamwerk wat op hierdie uitgangspunt geskoei is en die ondersoek gerig en gelei het, word vervolgens beskryf.

\section{Konseptueel- teoretiese raamwerk Deurlopende professionele ontwikkeling van onderwysers}

Deurlopende professionele ontwikkeling verwys na 'n proses van voortdurende deelname aan formele en informele professionele ontwikkelingsaktiwiteite om eie werksverrigting en leerderprestasies te verbeter (Kentucky Departement of Education 2010; Departement van Onderwys 2007). Die effektiwiteit van formele opleiding in die vorm van werkswinkels word dikwels bevraagteken (Darling-Hammond 2000) omdat administrateurs en beleidmakers die temas vir personeelontwikkeling kies (Bradley 1996). Verder is die fokus dikwels op die oordrag van inligting en kennis, met die gevolg dat onderwysers van belangrike geleenthede ontneem word om nuwe benaderings te toets om te besin hoe dit in die klaskamer gebruik kan word om leerderprestasies te bevorder (Bradley 1996). Hierdie scenario is nie onbekend in die Suid-Afrikaanse onderwysopset nie, soos nou aangetoon sal word.

Die staat het byvoorbeeld tydens die oorskakeling na Uitkomsgebaseerde Onderwys op werkswinkels staatgemaak

1.Die begrip 'sosiale band' (social tie) verwys na ' $n$ verhouding tussen ' $n$ paar in 'n gemeenskap wat die vloei van 'n sosiale bron (byvoorbeeld kennis, inligting, moontlik gemaak het. Die aanname word gemaak dat die band weer gebruik sal word en ook die vloei van ander sosiale bronne kan bewerkstellig.

2.'n Netwerk bestaande uit al die sosiale bande waarop onderwysers staatgemaak het om hul werk effektief te verrig. 
om die implementering van die beleid te bevorder. Die oneffektiwiteit van die professionele ontwikkeling van onderwysers tydens die oorskakeling na Uitkomsgebaseerde onderwys (Nieuwenhuis 2010) kan aan die oneffektiwiteit van die werkswinkelmetode toegeskryf word. Ondanks hierdie aanklag het die staat tydens die opleiding in 2012 en 2013 weer swaar op die werkswinkelmetode gesteun om onderwysers vir die Kurrikulum- en Assesseringsbeleidsverklaring op te lei. Die gebruik van werkswinkels om onderwysers in die Kurrikulum- en Assesseringsbeleidsverklaring op te lei, staan in sterk kontras met bepalings van die Geïntegreerde Strategiese Beplanningsraamwerk vir Onderwyseropleiding en -ontwikkeling in Suid-Afrika, 2011-2025 (Departemente van Basiese Onderwys en van Hoër Onderwys en Opleiding 2011:14). Die Plan het in die vooruitsig gestel dat die professionele leergemeenskapmodel onderwysers van geleenthede moes voorsien om die Kurrikulum- en Assesseringsbeleidsverklaring te verstaan en te gebruik. Volgens DuFour (2004) vind ware professionele ontwikkeling eers plaas wanneer onderwysers aangemoedig word om hoër kognitiewe vlakke tydens die leerproses te betrek. Dié geleenthede kan deur die professionele leergemeenskapmodel voorsien word.

\section{Professionele leergemeenskapmodel}

Daar is nie ' $n$ universele definisie vir die begrip 'professionele leergemeenskap' nie. Volgens Toole en Louis (2002) is navorsers dit egter eens dat die begrip na 'n groep mense verwys wat hul praktyke met mekaar deel en dié praktyke op 'n kritiese, volgehoue, reflektiewe, saamwerkende, inklusiewe, leergeoriënteerde en groeigerigte manier ondersoek om 'n gesamentlike doel te bereik. Volgens DuFour (2004) is 'n professionele leergemeenskap nie noodwendig 'n groep mense nie, maar eerder 'n volgehoue proses waarin onderwysers in siklusse van gesamentlike ondersoek en aksienavorsing saamwerk om beter leerderprestasies te lewer.

Die professionele leergemeenskapidee is nastrewenswaardig omdat dit bydra om kapasiteit in skole en stelsels te bou sodat leerderprestasies op 'n volhoubare wyse verbeter (kan) word (Bolam et al. 2005). Sulke leergemeenskappe beskik oor die vermoë om leer op alle vlakke in 'n skoolgemeenskap te bevorder omdat dit die gemeenskaplike doel is (Bolam et al. 2005). Professionele leergemeenskappe moet effektief met mekaar saamwerk, daarom is dit nodig om toe te sien dat die lede verbind is om eie sukses sowel as die sukses van die ander lede te bevorder. Dit kom ooreen met Johnson en Johnson (2013:19-20) se stelling dat effektiewe groepe hulle beywer om eie sukses sowel as dié van al die lede van die groep te bevorder. Die effektiwiteit van professionele leergemeenskappe word volgens Boolam et al. (2005) deur vier operasionele prosesse bepaal, naamlik:

- leierskap en bestuur

- optimalisering van bronne en strukture

- bevordering van individuele en gesamentlike leer

- evaluering en volhoubaarheid van die professionele leergemeenskap.
Die effektiwiteit van professionele leergemeenskappe hang verder van die volledige ontwikkeling van agt eienskappe af (Bolam et al. 2005), naamlik:

- gedeelde waardes en visie

- gesamentlike verantwoordelikheid dat leerders wel leer

- leergefokusde samewerking

- individuele en gesamentlike professionele leer

- reflektiewe professionele ondersoek

- openheid

- netwerke, en

- vennootskappe.

Die selfgerigtheid van onderwysers oefen egter ook ' $n$ invloed op die effektiwiteit van professionele leergemeenskappe uit. Die staat vereis van onderwysers om outonoom te kan fuksioneer. Dit impliseer dat 'n leerder (onderwyser) homof haarself as die bron van sy of haar eie gedrag beskou en in ooreenstemming met eie belangstellings en waardes optree, selfs wanneer die handelinge deur buitefaktore beïnvloed word (Guglielmino 2013). Die selfgerigtheid van onderwysers word egter deur werksomgewings beïnvloed. Werksomgewings wat individualistiese of mededingende leer bevorder, belemmer samewerking, aangesien onderwysers kan huiwer om belangrike inligting te deel om ' $n$ mededingende voordeel te bewerkstellig (DuFour \& DuFour 2012). Samewerking word aangemoedig in werksomgewings wat koöperatiewe leer na waarde skat. So 'n waardeskatting word moontlik gemaak omdat prestasie eers lof toegeswaai word wanneer beide die individu en sy of haar groep presteer. Onderwysers word tydens samewerkingsprosesse in netwerke van verhoudings verweef. Die fokus word vervolgens op die ontwikkelingsnetwerke in skoolomgewings geplaas.

\section{Die rol van ontwikkelingsnetwerke in skoolomgewings}

Volgens Wellman en Hampton (1999) was dit nog altyd verkeerd om gemeenskappe op grond van 'n spesifieke plek of groep - in plaas van die verhoudinge tussen hulle - te definieer. Tog het opvoedkundige navorsers eers teen die einde van die vorige eeu belangstelling begin toon in die sosiale verhoudinge tussen onderwysers - hoofsaaklik weens 'n gebrek aan 'n geskikte metode om dit wat in aanlynsosiale netwerke gebeur, te begryp (Schlager et al. 2009). Desnieteenstaande toon navorsing reeds dat inligtings-, kennis- (Cross \& Parker 2004; Printy 2008), raad-, leiding-, ondersteunings- (Sweitzer 2009; Cady, Meier \& Lubinsky 2006; Duncan-Howell 2010) en ervaringsnetwerke (Brimi 2006; Van Staden 2012) 'n belangrike rol ten opsigte van die werksverrigting van onderwysers en leerderprestasies speel. Dit is byvoorbeeld belangrik om die ondersteuningsnetwerke in skole te bevorder. Pittinsky (2005) het bevind dat 50\% van alle beginneronderwysers die praktyk binne die eerste drie jaar weens 'n gebrek aan ondersteuningsnetwerke verlaat.

Alhoewel opvoedkundige navorsers eers onlangs hierdie navorsingsveld betree het, was hulle tog van die eerste navorsers wat stelle sosiale bande (in plaas van enkele sosiale bande) bestudeer het om onderwysers se gedrag 
te verstaan. Baker-Doyle en Yoon (2011) het bevind dat beginneronderwysers 'doelbewuste professionele netwerke' skep om aktief by probleemoplossing betrokke te raak, ondersteuning te verkry, die norme van die skool te navigeer, 'n professionele status te ontwikkel en vertroue met betrekking tot hulle werk te bou. Volgens Roxa, Olsson en Martensson (2008) maak belangrike-ander-verhoudinge belangrike gesprekke in skoolomgewings moontlik indien hierdie verhoudinge deur die plaaslike kultuur ondersteun word. Die begrip 'persoonlike ontwikkelingsnetwerk' ${ }^{3}$ is onlangs geskep om te verwys na die stel sosiale bande wat onderwysers doelbewus skep om toegang tot kennis, inligting, raad, leiding, ondersteuning, ervaring en konkrete bronne te verkry om hul werksverrigting te bevorder (Van Staden 2012). Hierdie persoonlike ontwikkelingsnetwerke verweef onderwysers met onsigbare, onderliggende bande in groter ontwikkelingsnetwerke. Ontwikkelingsnetwerke stel onderwysers aan die praktyke van ander bloot, skep geleenthede om deel van die groter onderwysergemeenskap te word en kan as 'sosiale kapitaal' beskou word.

Die begrip 'sosiale kapitaal' het aanvanklik verwys na die gebruik van persoonlike netwerke om eie doelstellings en belangstellings na te streef (Galaskiewicz \& Wasserman 1993). Daar word egter tans geredeneer dat die begrip na veel meer as egosentriese doelbereiking verwys omdat die houding van individuele lede op 'n dinamiese wyse deur dié van ander lede beïnvloed word (Cross \& Parker 2004). Sosiale invloed is oorsaaklik, nie van persoonlike kontak afhanklik nie en hoef ook nie doelbewus te wees nie, daarom word die nabyheid van twee lede as 'n sterk voorspeller van hul invloed op mekaar se houdings beskou (Cross \& Parker 2004). Meer onlangs is die begrip 'praktykgebaseerde' of 'gemeenskaplike' sosiale kapitaal geskep om te verwys na die kennis en bronne wat onderwysers nodig het en waartoe sosiale netwerke in skoolomgewings (ontwikkelingsnetwerke) toegang bied.

'n Gedeelde kennisbasis en belowende praktyke is volgens DuFour en DuFour (2012:10) voorvereistes vir die vestiging van professionele leergemeenskappe. Tans word kennis as 'n belangrike organisatoriese bate beskou. Daar word geredeneer dat prestasie berus op wat lede weet en hoe goed nuwe kennis gebruik word om werksverrigting te bevorder. Sommige outeurs beskou sosiale kapitaal selfs belangriker as finansiële kapitaal, aangesien sosiale kapitaal die bereiking van doelstellings bevorder. Volgens Bolam et al. (2005) bevorder lerende organisasies praktykgebaseerde sosiale kapitaal indien inklusiewe lidmaatskap, wedersydse vertroue, respek, ondersteuning en 'n klem op die noodsaaklikheid dat professionele mense saam moet leer nagestreef word (Bolam et al. 2005). Indien geleenthede gebied word om uit eie geskiedenis en die beste praktyke van ander te leer, word dit wat geleer is vinnig en akkuraat deur die hele organisasie oorgedra (Bolam et al. 2005).

3.Die begrip ontwikkelingsnetwerk (Sweitzer 2009) verwys na die stel sosiale bande waarop doktorale studente staatmaak om raad, leiding en ondersteuning tydens die verloop van hul studies te verkry. Vanuit ' $n$ Sosiale Netwerk Analise-perspektief is so 'n stel sosiale bande eerder'n persoonlike ontwikkelingsnetwerk (Van Staden 2012). Die ' $n$ stel sosiale bande eerder' $n$ persoonlike ontwikkelingsnetwerk (Van Staden 2012). Die
begrip ontwikkelingsnetwerk verwys in hierdie artikel na die groter sosiale netwerk waarin die persoonlike ontwikkelingsnetwerke verweef is.
Dié oordrag van leer word weens die geïsoleerde aard van onderwysers se dagtaak gerem omdat onderwysers van geleenthede ontneem word om gereeld saam te werk (Bradley 1996; DuFour 2004). Die probleem kan egter deur die ontwikkeling van Leer 2.0-tegnologie ${ }^{4}$ oorkom word (Redecker, Alamutka \& Punie 2010; Van Staden 2012). Dit impliseer egter nie dat alle onderwysers die tegnologie sal gebruik om effektiewer persoonlike ontwikkelingsnetwerke te bou nie. Die effektiwiteit van persoonlike (ontwikkelings-) netwerke word volgens Carpenter, Bauer en Erdogan (2009) deur die volgende drie beginsels bepaal:

- simmetrie, of die moontlikheid dat 'n kollega weer sal help indien 'n probleem opduik

- ooreenkomstigheid, of die veronderstelling dat die uitruiltransaksie spontaan sal geskied as die twee betrokkenes se waardes, houding en kommunikasiepatrone ooreenstemmend is, en die

- uitruilbeginsel, of die aanname dat die uitruiltransaksie deur andersheid bevorder sal word omdat verskillende vaardighede en bronne betrek word.

Drie prosesse word tydens die gebruik van persoonlike netwerke betrek, te wete die vorming van sosiale bande, die instandhouding daarvan en die aktivering van die sosiale bande om toegang tot die bronne - wat deel van die persoonlike ontwikkelingsnetwerke vorm - te verkry. Onderwysers word tydens hierdie proses in groter ontwikkelingsnetwerke, wat deurlopende professionele ontwikkeling kan bevorder of rem verweef. Sosiale Netwerk Analise bied 'n geskikte metode om hierdie ontwikkelingsnetwerke te ontsluit om die deurlopende professionele ontwikkeling van onderwysers te moniteer.

\section{Sosiale Netwerk Analise as moniteringsmetode}

Volgens Cross en Parker (2004) is dit problematies as onderwysers onbewus is van die ervaring (sosiale kapitaal) wat in hulle netwerke verskuil lê. Hierdie sosiale kapitaal is onsigbaar, maar kan deur Sosiale Netwerk Analise ontbloot word. Daarom bied Sosiale Netwerk Analise 'n bruikbare metode om onderwysers se deurlopende professionele ontwikkeling in 'n Leer 2.0-tegnologie te beskryf, verstaan en ook te voorspel (Van Staden \& Van der Westhuizen 2013). Sosiale Netwerk Analise maak dit moontlik om gemeenskappe terselfdertyd op individuele, groeps- en gemeenskapsvlak te bestudeer om die hindernisse wat sosiale gedrag kan rem of verhoed te identifiseer. Dié metode maak dit egter terselfdertyd moontlik om die geleenthede wat sosiale gedrag kan bevorder, te identifiseer. Daarom veronderstel baie Sosiale Netwerk Analise-navorsers dat die suksesse en mislukkings van 'n gemeenskap of organisasie deur die interne patrone daarvan bepaal word. Sosiale Netwerk Analise bied die kennis, vaardighede en tegnieke om navorsers of onderwyserleiers gereeld van relevante, betroubare inligting te voorsien om hulle betyds in staat te stel om geskikte professionele ontwikkelingsaktiwiteite te voorsien om die werksverrigting van onderwysers te bevorder (Van Staden 2012).

4.Die begrip 'Leer 2.0-tegnologie' verwys na Web 2.0-tegnologie wat leerders in staat stel om eie inhoud te skep, toegang tot inhoud te verkry, saam te werk en sosiale bande met mekaar te vorm (Redecker, Alamutka \& Punie 2010). 
Vervolgens word die fokus op die implementeringsprobleme geplaas om geskikte strategieë te identifiseer om die implementering van 'n professionele leergemeenskapmodel in Suid-Afrikaanse konteks te bevorder.

\section{Strategieë om die implementering van die Suid-Afrikaanse professionele leergemeenskapmodel te bevorder}

Verskeie van die bepalings en vereistes wat die Plan ten opsigte van die Suid-Afrikaanse professionele leergemeenskapmodel stel (Departemente van Basiese Onderwys en van Hoër Onderwys en Opleiding 2011), word deur navorsers onderskryf (Papastamatis et al. 2009; Bolam et al. 2005; DuFour \& DuFour 2012; DuFour 2013). Alhoewel die voorgestelde professionele leergemeenskapmodel die deurlopende professionele ontwikkeling van onderwysers kan bevorder, hang die sukses van die model van die suksesvolle implementering daarvan af. Volgens Pittinsky (2005) bestaan daar ' $n$ al groter wordende ongelykheid tussen die groeiende behoefte om die deurlopende professionele ontwikkeling van onderwysers te bevorder en die vermoë om geskikte professionele ontwikkelingsaktiwiteite betyds, doeltreffend en koste-effektief te voorsien. Hierdie drie kriteria het as basis vir die keuse van geskikte strategieë gedien. Die implementeringsprobleme en geskikte strategieë om die probleme die hoof te bied, word vervolgens bespreek.

\section{Ontwikkeling van Leer 2.0-tegnologie om vir die gebrek aan vergaderplekke te vergoed}

Die staat beoog om Distriksonderwyserontwikkelingsentra (District Teacher Development Centres [DTDC's]) op te rig en toe te rus om as vergaderplekke vir professionele leergemeenskappe op distriksvlak te dien. Weens die finansiële implikasies daarvan sal slegs sommige van hierdie projekte teen 2023 gereed wees (Departemente van Basiese Onderwys en van Hoër Onderwys en Opleiding 2011:12-13). Dit impliseer aan die een kant dat die vergaderplekke nie betyds, doeltreffend of koste-effektief voorsien kan word nie. Aan die ander kant impliseer dit dat onderwysers, weens die gebrek aan geskikte vergaderplekke, moontlik nie daarin sal slaag om professionele leergemeenskappe te vestig nie.

Die gebrek aan geskikte vergaderplekke kan deur die ontwikkeling van Leer 2.0-tegnologie die hoof gebied word (Van Staden 2012). Web 2.0-tegnologie beskik oor potensiaal om die aard van leer en onderrig fundamenteel te verander as leerdernetwerke geskep word, daarom behoort daar gereed gemaak te word om Leer 2.0-tegnologie te implementeer om leer te bevorder (Brown 2010). Volgens Duncan-Howell (2010) bied aanlyn sosiale netwerke 'n bron vir deurlopende professionele ontwikkeling omdat unieke, verpersoonlikte leergeleenthede voorsien kan word. Leer 2.0-tegnologie kan betyds, doeltreffend en koste-effektief voorsien word om leer te bevorder, mits hierdie tegnologie onderwysers van geleenthede voorsien om (Duncan-Howell 2010):
- self inhoud te skep

- toegang tot inhoud te verkry

- saam te werk, en

- sosiale bande met ander te vorm.

Daar bestaan 'n interafhanklikheid tussen Leer 2.0-tegnologieë en deelname aan professionele ontwikkelingsaktiwiteite. Navorsing toon dat die vier eienskappe van 'n Leer 2.0-tegnologie binne drie maande tydens deelname aan geskikte professionele ontwikkelingsaktiwiteite ontwikkel het, terwyl die tegnologie terselfdertyd geleenthede gebied het om te enige tyd of plek aan geskikte professionele ontwikkelingsaktiwiteite deel te neem (Van Staden 2012). 'n Bykomende voordeel is dat gebruikers - anders as in die fisiese leeromgewing - toegang tot die presiese gedeelde sosiale kapitaal kan verkry om passiewe leer moontlik te maak (Schlager et al. 2009). Volgens Goggins, Laffey en Gallagher (2011) kan 'n gebrek aan genoegsame geleenthede om aan professionele ontwikkelingsaktiwiteite deel te neem, effektief deur sosiotegnologiese netwerke oorkom word. Die ondersteuning van die portuur kan weerstand teen tegnologie afbreek en toegang tot elektroniese leeromgewings bevorder (Henning \& Van der Westhuizen 2004). Volgens Laferriere, Lamon en Chan (2006) kan onderwysers 'n sleuterol in die verbetering van die onderwys speel indien hulle van geleenthede voorsien word om eie leer te besit en te ontwerp. Die stelling is onlangs bevestig. Die wiskundeonderwysers wat aan 'n studie deelgeneem het, het binne drie maande hul eie leer besit en ontwerp (Van Staden 2012). Daardeur het die gebruik van Leer 2.0-tegnologieë daartoe bygedra dat 'n toeganklike, gedeelde kennisbasis opgebou word.

Die gehalte van die gedeelde kennisbasis- of praktykgebaseerde sosiale kapitaal - word egter deur die soort leer wat bevorder word, beïnvloed. Beide individualistiese en mededingende leer kan die vloei van inligting, kennis, raad, leiding, ondersteuning, ervaring en konkrete bronne in die werksomgewing rem en selfs verhoed dat onderwysers saamwerk. Indien die probleem geïdentifiseer word, behoort dit so gou moontlik die hoof gebied te word. Volgens Cross en Parker (2004) is 'n gebrek aan vloei van inligting vir die meeste mense grotendeels sigbaar ten opsigte van persoonlike produktiwiteit, leer- en beroepskeuse. Aangesien Leer 2.0-tegnologieë te enige tyd en plek beskikbaar is en sinchroniese sowel as asinchroniese interaksie moontlik maak, kan die gebruik van hierdie tegnologie daartoe bydra dat die vloei van inligting bevorder word. Volgens Cuthell (2002) verteenwoordig nuwe tegnologieë beide die netwerk vir kommunikasie en die geheue van die gemeenskap. Hierdie eienskappe van Leer 2.0-tegnologie kan die volhoubaarheid van die professionele leergemeenskappe bevorder. Die beskikbaarstelling van Web 2.0 en die ontwikkeling van Leer 2.0-tegnologie kan egter nie verseker dat onderwysers die tegnologie sal gebruik om saam te leer nie (Van Staden 2012). Geskikte strategieë behoort in plek gestel te word om samewerking tussen onderwysers te bevorder. 


\section{Vestiging van koöperatiewe basisgroepe om samewerking tussen onderwysers te bevorder}

Volgens die Plan ${ }^{5}$ moet vakgebaseerde professionele leergemeenskappe in skole, distrikte, ensovoorts, gevestig word (Departemente van Basiese Onderwys en van Hoër Onderwys en Opleiding 2011) om onderwysers van geleenthede te voorsien om hul eie leerbehoeftes te identifiseer en die weg ruim. Onlangse navorsing (Van Staden 2012) toon egter dat so 'n groep onderwysers nie noodwendig as 'n professionele leergemeenskap geklassifiseer kan word nie. Sommige van die onderwysers het op die rûe van kollegas gery. 'n Bestudering van die resultate van die betrokke navorsing toon egter ook dat daar tekens van individualistiese en mededingende leer teenwoordig was en dat die onderwysers nie saamgewerk het om 'n gemeenskaplike doel te bereik nie. Een van die onderwysers se werk was byvoorbeeld nie betyds vir 'n besoek van die distriksbestuur gereed nie, alhoewel al haar kollegas se werk gereed was. Daaruit kan afgelei word dat die groep onderwysers eerder as 'n tradisionele werksgroep (Johnson \& Johnson 2013) geklassifiseer kan word. Tradisionele werksgroepe is volgens Johnson en Johnson nie gemotiveerd om mekaar in te lig nie, aangesien die lede individueel verantwoordelik gehou word en nie as 'n span nie (Johnson \& Johnson 2013:19). Die probleem kan opgelos word indien onderwysers van geleenthede voorsien word om saam te leer.

Volgens DuFour en DuFour (2012:10) moet onderwysers weet waarom hulle by die proses betrokke is sodat hulle besluite kan neem om saam te leer. Daarom behoort onderwysers gemotiveer te word om so 'n gemeenskaplike doel te bereik. Die geskiktheid van ekstrinsieke motivering, wat deur die Deurlopende Professionele Onderwyserontwikkelingstelsel (DPOO-stelsel) voorgestaan word (Departement van Onderwys 2007), word egter bevraagteken. Hierdie aanvullende moniteringstelsel beoog om onderwysers te straf wat nie aan geskikte professionele ontwikkelingsaktiwiteite deelneem nie. So 'n wortel-en-stokbenadering ('n benadering van beloning of straf) kan juis die teenoorgestelde uitwerking hê. Volgens Guglielmino (2013) kan ekstrinsieke motivering intrinsieke motivering versmoor, prestasie verlaag, kreatiwiteit onderdruk, goeie gedrag oorheers, verslawend word, korttermyndenke bevorder en skelmstreke, kortpaaie en onetiese gedrag aanmoedig. Oorafhanklikheid van ekstrinsieke motivering is nie alleen verouderd nie, dit is ook skadelik (Pink 2009). Daarom behoort geskikte strategieë in plek gestel te word om intrinsieke motivering te stimuleer.

Een so 'n strategie is om koöperatiewe basisgroepe te vestig. Die begrip 'koöperatiewe basisgroep' verwys na een van die kleingroeptegnieke wat gebruik kan word om koöperatiewe leer te bevorder. Koöperatiewe leer word volgens Jonhson en Johnson (2013) gekenmerk deur:

- positiewe interafhanklikheid

- individuele verantwoordelikheid

- sosiale vaardighede

5.Verkorte naam van die Geïntegreerde Strategiese Beplanningsraamwerk vi Onderwyseropleiding en Ontwikkeling in Suid-Afrika, 2011- 2025.
- bevorderlike interaksie, en

- groeprefleksie.

Koöperatiewe basisgroepe toon belangrike ooreenkomste met die groepe onderwysers wat deur hiërargiese strukture in skole saamgevoeg word om 'n spesifieke graad of vak te onderrig. In beide gevalle is die groepe heterogeen, lidmaatskap stabiel en word die lede oor 'n lang tyderk vir 'n gesamentlike doel verantwoordelik gehou. Anders as in die geval van koöperatiewe basisgroepe wat toegewyd en gemotiveerd word sodra hulle besef dat hulle vir 'n lang tydperk gaan saamwerk (Johnson, Johnson \& Holubec 2008), toon onlangse navorsing dat dit nie noodwendig waar is ten opsigte van die tradisionele werksgroepe (hiërargiese strukture) in skole nie.

Verskeie van die groepe onderwysers (graadonderwysers) was na nege maande nie gemotiveerd om mekaar te ondersteun nie, met nadelige effek op hul eie werksverrigting en dié van kollegas (Van Staden \& Van der Westhuizen 2013). Daarom kan sodanige groepe eerder as tradisionele werksgroepe beskryf word. Volgens Johnson en Johnson (2013) maak individuele verantwoordbaarheid dit vir sommige lede van tradisionele werksgroepe moontlik om op hardwerkendes se rûe te ry. Die navorsing van Van Staden (2012) toon dat die hardwerkende departementshoof toegelaat het dat verskeie van die graadkoördineerders op haar rug ry. Sy het hul taak oorgeneem om die werksverrigting van haar departement te bevorder, maar haar werkslas het daardeur in so mate vergroot dat sy die skool teen die einde van daardie jaar verlaat het (Van Staden 2012).

Om tradisionele werksgroepe in professionele leergemeenskappe te ontwikkel, is dit noodsaaklik om koöperatiewe leer te bevorder. Koöperatiewe basisgroepe bied 'n geskikte strategie, aangesien onderwysers:

- mekaar in die voltooiing van opdragte ondersteun

- mekaar aanmoedig, en

- mekaar vir die strewe om te leer verantwoordelik hou.

Die doel van die professionele leergemeenskapmodel is om onderwysers te bemagtig om self die verantwoordelikheid vir eie professionele ontwikkeling te dra. Volgens DuFour en DuFour (2012:9) is dit noodsaaklik om te verseker dat bemagtigde groepe toegang tot inligting verkry. Sosiale Netwerk Analise bied 'n geskikte strategie om te bepaal of onderwysers toegang tot inligting kan verkry.

\section{Sosiale Netwerk Analise as metode om samewerking tussen onderwysers te moniteer en bevorder}

Navorsers fokus dikwels op buite-faktore om effektiwiteit van professionele leergemeenskappe te bevorder. Volgens Bolam et al. (2005) kan gereelde monitering van die eienskappe en implementeringsprosesse bydra dat geskikte stappe geneem kan word om professionele leergemeenskappe meer effektief te maak. DuFour (2013) fokus weer op stadia van professionele leergemeenskappe om effektiwiteit te bevorder. Beide 
benaderings kan tydrowende data-insamelingsprosedures vereis sonder om relevante, betroubare inligting beskikbaar te stel om samewerking in professionele leergemeenskappe te bevorder.

Daar bestaan ' $n$ behoefte aan nuwe metodes om die interaksie in aanlynomgewings te evalueer (Martinez et al. 2003). Daar is onlangs bevind dat kennisbestuurstrategieë leer in spanverband aanmoedig en onderwysers leer om kennis te deel, saam te werk en prestasiebeoordelingsmeganismes vir kennistoepassing en -ontwikkeling te skep (Zhao 2010). Zhang (2009) het bevind dat die hoogste vlakke van kollektiewe kogniese verantwoordelikheid, verbeterde kennis en dinamiese diffusie voorgekom het toe opportunistiese samewerking in klein groepe rondom 'n ontluikende doel toegelaat is. Daarom behoort die fokus op die samewerkingsproses geplaas te word om die effektiwiteit van professionele leergemeenskappe te bevorder.

Die geskikste metode om inligting oor die samewerkingsproses in te samel, is Sosiale Netwerk Analise. Hierdie metode stel navorsers in staat om terselfdertyd op die individu, die groep en die gemeenskap te fokus om hindernisse te identifiseer wat samewerking kan bevorder, rem of verhinder. Gereelde analisering van ontwikkelingsnetwerke kan onderwyserleiers van relevante, betroubare inligting voorsien (Van Staden 2012) om die samewerkingsproses te moniteer. Die voorspellingswaarde van Sosiale Netwerk Analise kan onderwyserleiers in staat stel om professionele ontwikkelingsaktiwiteite betyds beskikbaar te stel (Van Staden \& Van der Westhuizen 2013) om die samewerkingsproses te bevorder. Navorsing toon dat die metode gereeld driemaandeliks - en koste-effektief gebruik kon word om geskikte professionele ontwikkelingsaktiwiteite beskikbaar te stel om die deurlopende professionele ontwikkeling van die wiskundeonderwysers van 'n sekondêre skool betyds en doeltreffend te bevorder (Van Staden 2012).

Na aanleiding van die bostaande bespreking van strategieë om die geïdentifiseerde implementeringsprobleme die hoof te bied, word die implikasies vir die onderwys vervolgens bespreek.

\section{Implikasies van professionele leergemeenskap-model vir die onderwys: Enkele aanbevelings}

Die Suid-Afrikaanse professionele leergemeenskapmodel kan deur drie belangrike implementeringsprobleme in die wiele gery word. Die volgende strategieë word aanbeveel om daartoe by te dra dat die model betyds, doeltreffend en koste-effektief geïmplementeer kan word:

- Die ontwikkeling van Leer 2.0-tegnologie om as vergaderplekke vir professionele leergemeenskappe te dien.

- Die koestering van koöperatiewe basisgroepe om samewerking tussen onderwysers te bevorder.

- Gereelde Sosiale Netwerk Analises om die samewerkingsproses te moniteer.
Hierdie drie strategieë kan moontlik daartoe bydra dat die model vaartbelyn in Suid-Afrikaanse konteks geïmplementeer kan word. Daarom word daar aanbeveel dat empiriese navorsing gedoen word om die bruikbaarheid daarvan in werklike skoolomgewings te ondersoek.

\section{Slot}

Die regte verbindings tussen onderwysers kan 'n merkbare impak op die werksverrigting van onderwysers en leerderprestasies uitoefen. Daarom behoort Sosiale Netwerk Analise gereeld gebruik te word om die onsigbare, onderliggende ontwikkelingsnetwerke in skoolomgewings te verken. Die doel daarvan behoort te wees om hindernisse wat die werksverrigting van onderwysers kan rem te identifiseer. Dié inligting kan onderwyserleiers in staat stel om geskikte professionele ontwikkelingsaktiwiteite te identifiseer, ontwerp of ontwikkel om die deurlopende professionele ontwikkeling van onderwysers te bevorder. Professionele leergemeenskappe kan nie aan hul eie genade oorgelaat word nie. Die model behoort daarom op 'n gekoördineerde wyse bestuur te word om te verseker dat die model vaartbelyn in Suid-Afrikaanse konteks geïmplementeer kan word.

\section{Erkenning Mededingende belange}

Die outeurs verklaar dat hulle geen finansiële of persoonlike verhouding(s) het wat hulle op 'n onvanpaste wyse in die skryf van die artikel beïnvloed het nie.

\section{Outeursbydrae}

C.J.v.S. (Noordwes-Universiteit) was vir die ontwerp van die projek verantwoordelik. E.M. (Noordwes-Universiteit) het betekenisvolle konseptuele bydraes gemaak.

\section{Literatuurverwysings}

Baker-Doyle, K. \& Yoon, S.A., 2011, 'In search of practitioner-based social capital: A Social Network Analysis Tool for understanding and facilitating teacher collaboration in a US-based STEM professional development program', Professional Development in Education 37 (1), 75-93.

Barth, R.S., 1997, The principal learner: A work in progress, Harvard Graduate International network of principal's centers, School, Cambridge.

Bolam, R., McMahon, A., Stoll, L., Thomas, S. \& Wallace, M., 2005, Creating and sustaining effective professional learning communities, Research Report RR637, Department for Education and Skills, University of Bristol, Bristol.

Bradley, A., 1996, 'Inquiring minds: The missing link', Education week 15(30), 5-9.

Brimi, H., 2006, 'Ten tips for steering the teaching internship into a real career starter', Clearing House 79 (4), 164-169.

Brown, S., 2010, 'From VLEs to learning webs: The implications of Web 2.0 for learning and teaching', Interactive Learning Environments 18(1), 1-10.

Cady, J., Meier, S.L. \& Lubinski, C.A., 2006, 'Developing mathematics teachers: The transition from preservice to experienced teacher', Journal of Educational Research 99(5), 295-305.

Carpenter, M., Bauer, T. \& Erdogan, B., 2009, Principles of Management, Flat World Knowledge, viewed on 20 August 2013 from http://catalog.flatworldknowledge. $\mathrm{com} /$ catalog/editions/carpenter-principles-of-management-1-0

Cross, R. \& Parker, A., 2004, The hidden power of social networks: Understanding how work really gets done in organizations, Harvard University Press, Boston.

Cuthell, J., 2002, 'A learning community - a community of learners', Journal of Interactive Learning Research: Special issue: Distributed cognition for learning) 13(1-2), 167-186.

Darling-Hammond, L., 2000, 'Teacher quality and student achievement: A review of state policy evidence', Education Policy Archives 8. 
Department of Education, 2007, National Education Policy Act (27/1996): National Policy Framework for Teacher Education in South Africa, nr. 502, 29832, Government Gazette, Pretoria.

Departemente van Basiese Onderwys en Hoër Onderwys en Opleiding, 2011, Geïntegreerde Strategiese Beplanningsraamwerk vir Onderwyseropleiding en Ontwikkeling in Suid-Afrika, 2011-2025, Departemente van Basiese Onderwys en van Hoër Onderwys en Opleiding, Pretoria.

Didloft, V.C., 2010, 'Enhancing self-esteem as a teacher of English using action research, D.Ed thesis', Nelson Mandela Metropolitan University, Port Elizabeth, viewed on 13 August 2013 from http://www.nmmu.ac.za/documents/theses/VIRGINIA\%20 CHARMAINE\%20DIDLOFT\%20.pdf

Duncan-Howell, J., 2010, 'Teachers making connections: Online communities as a source of professional learning', British Journal of Educational Technology 41(2), 324-340.

DuFour, R., 2004, 'What is a professional learning community?' Educational Leadership 61(8), 6-11.

DuFour, R. \& DuFour, R., 2012, The school leader's guide to professional learning communities at work, Solution Tree Press, Bloomington.

DuFour, B., 2013, Is departmentalization an approved practice in the PLC at workTM process?, viewed on 03 August 2013 from http://www.allthingsplc.info/wordpress

Galaskiewicz, J. \& Wasserman, S., 1993, 'Social Network Analysis: Concepts, methodology and directions', Sociological Methods Research 11, 3-22.

Goggins, S., Laffey, J. \& Gallagher, M., 2011, 'Complete online group formation and development: Small groups as socio-technical systems', Information Technology and People 24(2), 104-133.

Guglielmino, L., 2013, 'Fostering self-directed learning: The challenges and rewards', paper delivered at congress on self-directed learning, April 2013, North-West University, Potchefstroom.

Hegerhahn, B. \& Olsen, M., 1992, An introduction to theories of learning, 4th edn., Prentice-Hall Inc, New Jersey.

Henning, E. \& Van der Westhuizen, D., 2004, 'Crossing the digital divide safely and trustingly: How ecologies of learning scaffold the journey', Computers and Education 42(4), 333-352.

Johnson, R. \& Onwuegbuzie, A.J., 2004, 'Mixed methods research: A research paradigm whose time has come', Educational Researcher 33(7), 14-26.

Johnson, D.W. \& Johnson, F.P., 2013, Joining together: Group theory and group skills, 11th edn., Pearson, Boston.

Johnson, D.W., Johnson, R.T. \& Holubec, E.J., 2008, New Circles of learning: Cooperation in the classroom and school, 4th edn., Interaction Book Company, Edina, MN.

Kentucky Department of Education, 2010, Professional development, viewed on 28 March 2010, from http://www.education.ky.gov/KDE/Administrative\%2BResources/ Professional\%2BDevelopment.

Laferriere, T., Lamon, M. \& Chan, C., (2006), 'Emerging e-trends and models in teacher education and professional development', Teaching Education 17(1), 75-90. http:// dx.doi.org/10.1080/10476210500528087

Martínez, A., Dimitriadisl, Y., Rubia, B., Gómez, E. \& De la Fuente, P., 2003, ‘Combining qualitative evaluation and social network analysis for the study of classroom social interactions', Computers and Education 41(4), 353. http://dx.doi.org/10.1016/j. compedu.2003.06.001
Nieuwenhuis, J., 2010, Onderwys in Suid-Afrika - 'n Pandora se kruik. 'n Besprekingsdokument vir die Afrikanerbond met moontlike strategieë om die onderwysvraagstuk aan te spreek, Afrikanerbond, Pretoria.

Papastamatis, A., Panitsidou, E., Giavrimis, P. \& Papanis, E., 2009, 'Facilitating Teachers' \& Educators' Effective Professional Development', Review of European Studies 16(2), 83-90

Pink, D.H., 2009, Drive: The surpising truth about what motivates us, River Head Books, New York.

Pittinsky, M., 2005, 'No Teacher Left Behind', Technological Horizons in Education 32(11), 32-34.

Printy, S., 2008, 'Leadership for teacher learning: A community of practice perspective', Educational Administration Quarterly 44(2), 187-226.

Redecker, C., Ala-Mutka, K. \& Punie, Y., 2010, Learning 2.0-The impact of social media on learning in Europe, European Commission, Joint Research Centre, Institute for Prospective Technological Studies, Seville.

Roxa, T., Olsson, T. \& Martensson, K., 2008, 'Appropriate use of theory in the scholarship of teaching and learning as a strategy for institutional development' Research and Practice 7(3), 276-294.

Schlager, M., Farooq, J., Schlank, P. \& Dwyer, N., 2009, 'Analyzing online teacher networks: Cyber Networks require Cyber Research Tools', Journal of Teacher Education 60(1) 86-100.

Sweitzer, V., 2009, 'Towards a theory of doctoral student professional identity development: A developmental networks approach', The Journal of Higher Education 80(1), 33.

Toole, J.C. \& Louis, K. S., 2002, 'The Role of Professional Learning Communities in International Education', in K. Leithwood \& P. Hallinger (eds.), Second International Handbook of Educational Leadership and Administration, Kluwer, Dordrecht. http:// dx.doi.org/10.1007/978-94-010-0375-9_10

Van Staden, C.J., 2012, Sosiale Netwerk Analise as metode om die deurlopende professionele ontwikkeling van die wiskundeonderwysers van 'n sekondêre skool in Gauteng te moniteer, PhD-tesis, Dept van Wetenskap en Tegnologie, Universiteit van Johannesburg, Johannesburg.

Van Staden, C.J. \& Van der Westhuizen, D., in press, 'Learn 2.0-technologies and the continuing professional development of secondary school mathematics teachers', Journal for New Generation Sciences 11(2).

Veugelers, W. \& Zijlstra, H., 2002, 'What goes on in a network? Some Dutch experiences', International Journal of Leadership in Education 5(2), 163-174.

Weems, C., 1999, 'Pshycological inquiry and the role of world views', Behaviour and Psychology, viewed on 1 January 2011, from http://findarticles.com/p/articles / mi_qa3814/is_199910/ai_n8853672/pg_4/

Wellman, B. \& Hampton, K., 1999, 'Living networked on and off line' Contemporary Sociology 28(6), 648-654.

Zhang, J., Scardamalia, M., Reeve, R. \& Messina, R., 2009, 'Designs for collective cognitive responsibility in knowledge-building communities', Journal of the Learning Sciences 18(1), 7-44.

Zhao, J., 2010, 'School knowledge management framework and strategies: The new perspective on teacher professional development', Computers in Human Behavior 26(2), 168-175 